\title{
EXCERPTS FROM THE ANNUAL CSP CONGRESS IN LONDON HELD AT THE ROYAL FREE HOSPITAL IN HAMPSTEAD
}

A lecture by $\mathrm{Dr}_{\mathrm{r}}$ Gres Grieve on lumbar instability was perhaps the highlight of the congress. A prècis of it could never do justice to the information and researched facts presented, but the essential theme was that lumbar instability and hypermobility are factors often overlooked by physiotherapists in the assessment and treatment of lumbar pain.

The causes, briefly, are:

- Generalised disc degeneration (kissing spine).

- Iatrogenic (consequence of surgical fusion).

- Postpartum abnormality.

- Single localised mechanical strain.

- Chronic localised degenerative changes.

- Naturally hypermobile spine (heredity).

Neoplasms.

The conservative treatment, according to Grieve, is to teach stabilisation exercises, viz. gentle lumbar flexion such as:

- Crook lying; dynamic abdominal bracing.

- Crook lying; flex head and neck; holding as long as it takes to say your name and address.

- Crook lying; hands behind head; contraction of oblique abdominals.

- Prone ly; 2 leg extension; progress by placing small pillow across the ankles.

- Prone ly; static contraction of back extensors at a segmental level, e.g. L4 - 5 instability, physiotherapist places thumb over level and patient practises localised static contraction.

- Prone lying; progress above exercise by placing pillow under abdomen, legs over edge of bed; localised hold/relax at required level.

- Sitting, patient's thumb over required level; localised hold/relax.

An unstable joint should never be manipulated, but the hypomobile joint above or below the level should be mobilised. If a lumbar support is required, never supply it without a plan to eventually eliminate it, and at all costs restore confidence to the patient and give him a positive outlook.

In Britain, 24 million working days are lost each year due to back injury, costing the country $£ 1000$ mil- lion a year. Prevention of back disorders is the function of the materials handling research unit. The lecture by Dr D. A. Stubbs on Back Problems in Work and Leisure was based on a recent research on nurses and adolescent water-ski jumpers. It was found that the injuries were caused by the accumulation of repeated trauma. In the case of nurses, the intra-abdominal pressure (IAP) was measured during the activities of lifting patients in bed, and it was found that if the spinous stress was exceeded often enough during the day, a back problem resulted. It was found that the Australian or shoulder lift placed much less stress on the back whereas the orthodox lift caused excessive IAP.

Of the adolescent water-ski jumpers, $47 \%$ had lumbar and thoracic pain. By using measuring devices attached to the head of femur, iliac crest and lateral malleoli, he found that the force of pressure at ramp site was $16 \mathrm{G}$ (1G force is required to keep us on the ground) and because skiers practise frequently, the accumulation of $G$ shocks leads to joint trauma, and the research unit advised the appropriate authorities to ban ski jumping for under 16-year-olds.

The Association of Sports Medicine held a meeting in which they appealed to physiotherapists in general, and younger ones in particular, to take a voluntary interest in the sports injuries of their local clubs, thereby not only propagating the role of physiotherapy in sport, but also aiding the athletes and gaining useful on-site experience. If physiotherapists do not do this, far less qualified people will step into the breach. Basically, the on-site physiotherapist would have to learn to observe the injury as it occurs, to assess the seriousness of the damage and to advise as to rest, strapping, ice, etc., or to call for further medical advice. The sportsman receives an unbelievable barrage of repeated trauma to the skeletal system, but his courage and determination to continue makes physiotherapy involvement in sports medicine so gratifying. The lecturer cited the example of the blind physiotherapist, who recently climbed Mt. Everest, and blind amputees in Britain who go water-skiing.

Patricia Swilling

\section{CANADIAN PHYSIOTHERAPY ASSOCIATION}

In June 1981, the Board of Directors of the Canadian Physiotherapy Association approved revisions to the policies and procedures governing eligibility for membership in the Association for physiotherapists educated outside Canada. The revisions are designed to provide a process which is equitable to all physiotherapists educated outside Canada and to ensure that educational requirements and ethical standards required for membership in the Association are maintained at a level at least equivalent to that of a Canadian graduate who holds a baccalaureate degree in physiotherapy.

The procedures set forth below describe the mechanism for physiotherapists who are eligible to practise in any country other than Canada to become eligible for membership in the Canadian Physiotherapy Association.

On and after September 30, 1982, for physiotherapists applying for membership in the Canadian Physiotherapy Association who have received their physiotherapy education outside Canada, the following will be required:
(1) graduation from a school of physiotherapy, and eligibility for membership in the professional association of the country of graduation;

(2) demonstration of proficiency in either English or French, if neither language is the applicant's mother tongue;

(3) successful completion of written screening examination;

(4) successful completion of a clinical residency in an accredited facility in Canada.

Applicants must successfully complete each step in the order set out above before they are permitted to proceed to the next step.

To permit a smooth transition from the present to the new regulations. the following interim arrangements have been adopted for applicants from South Africa:

Physiotherapists who received their physiotherapy education in South Africa will be admitted to membership in the Canadian Physiotherapy Association 
without examination or clinical residency provided:

(1) they are members of the national association or eligible for such membership;

(2) the application for membership is postmarked prior to September 30, 1982;

(3) registration is completed by March 31, 1983.

\section{PRIVATE PRACTITIONERS' ASSOCIATION Change of Secretary}

Please note that the Acting Secretary is: Mrs. P. Pilkington, 59 Alma Road, ROSEBANK 7700. Telephone: (021) 69-2419.

\section{EXCHANGE SYSTEM}

Physiotherapists who wish to work or study in Germany have to make individual arrangements as no exchange system exists at present. Of course the physiotherapist who wants to work in Germany should know the German language. They are advised to contact the hospitals and schools in:

\section{Heidelberg}

Rehabilitationsklinik

Herr Prof. Dr. med. Schimpf,

Bonhoefferstr. 1, D-6900 Heidelberg 1

Staatl. anerk. Schule für Krankengymnastik

a.d. Orthop. Klinik und Poliklinik der Universität Heidelberg

Herr Prof. Dr. med. H. Cotta

Schlierbacher Landstra $\beta$ e 200a, D-6900 Heidelberg 1

\section{Karlsbad}

Rehabilitationskrankenhaus

Herr Prof. Dr. med. Bister

Guttmannstr. 1, D-7516 Karlsbad 1

Staatl. anerk. Schule für Krankengymnastik am Rehabilitationskrankenhaus Karlsbad-Langensteinbach Herr Dr. med. K. Brinkmann

Guttmannstr. 1, D-7516 Karlsbad 1

Deutscher Verband für Physiotherapie - Zentralverband der Krankengymnasten (ZVK) e.V. - Landesverband Baden-Württemberg e.V. -

Herr J. Grete, 1. Vorsitzender

Wiederhaoldstr. 25 , D-7000 Stuttgart 1

\section{Bischofswiesen}

Rehabilitationszentrum und Kurklinik Loipl

Herr Heliek

D-8242 Bischofswiesen

\section{Murnatı}

Berufsgenossenschaftliche Unfallklinik

Herr Prof. Dr. med. J. Probst

Professor-Küntscher-Str. 8, D-8110 Murnau

Deutscher Verband für Physiotherapie - Zentralverband der Krankengymnasten (ZVK) e.V. - Landesverband Bayern e.V. -

Frau J. von Busekist

Barer-St. 86a, D-8000 München 40
Damp

Ostseeklinik Damp 2000

D-2335 Damp

Staatl. anerk. Lehranstalt für Krankengymnastik an der Ostseeklinik Damp

Herr Prof. Dr. med. H. Schoberth

D-2335 Damp 2

\section{Kiel}

Staatl. anerk. Lehranstalt für Kranķengymnastik

Dr. Lubinus Kiel

Herr Dr. med. H. Lubinus

Dahlmannstr. 1-3, D-2300 Kiel 1

Deutscher Verband für Physiotherapie - Zentralverband der Krankengymnasten (ZKV) e.V. - Landesverband Hamburg und Schleswig-Holstein e.V. -

Frau L.-Ch. Hadank, 1. Vorsitzende Innocentia-Str. 42, D-2000 Hamburg 13

Please contact the chairmen of the physical therapy branches which are regionally in contact with those centres. So far an exchange system does not exist because of language problems and the different standards in physical therapy.

\section{SUB-COMMITTEE ON RESEARCH}

It was suggested at Council that the feasibility of establishing a co-ordinating committee on Research should be investigated. It was felt that this could be of value to individual members of the Society and to the profession as a whole. A sub-committee has been convened to establish whether there is a need to co-ordinate research. If a need is found, the objectives of the sub-committee will be:

1. To set up a register of all research that is being done by physiotherapists in this country.

2. To direct members who are interested in research to persons who are working in the same field.

3. To publish twice yearly a list of researchers with a brief description of their research.

If you are involved in research or clinical trials or are interested in doing research, please send the following information to the Chairman of Research, S.A.S.P., P.O. Box 11151, Johannesburg, 2000. Name, address and research interest; whether registered for a higher degree; interested in receiving a copy of the list of research workers; prepared to assist other research workers in your specialised field.

THE SOUTH AFRICAN PSORIASIS ASSOCIATION Registered with the Department of Health, Welfare and Pensions

W.O. 02200490007

Aims are:

(1) To collect money for more research projects into the causes, treatment and cure of psoriasis.

(2) To educate the general public about the disease.

(3) To provide support and mutual aid for the sufferers by setting up branches and groups in order to discuss cominon problems related to this disease.

It is hoped that this Association will receive your support.

For further information contact: Mrs. A. Weiner, MCSP, 106 Herbert Baker Street, Groenkloof, Pretoria. 
VII COMMONWEALTH AND INTERNATIONAL CONFERENCE IN SPORT, PHYSICAL EDUCATION AND DANCE

Brisbane, Queensland, Australia.

September 23 - 28th, 1982

\section{"PHYSIOTHERAPY IN SPORT"}

\section{CALL FOR PAPERS}

'Conference 82' is being held at the UNIVERSITY OF QUEENSLAND in the week prior to the 1982 COMMONWEALTH GAMES.

There are several areas of interest within the Conference, including a section relating to Physiotherapy in Sport. This has three major streams:

Subsections

Principal speaker

Management of Sporting

Dr. D. Reid (Canada)

Injuries

Injury Prevention

Professor V. Janda

(Czechoslovakia)

hysiotherapy care of Dr. R. Quirk (Australia) the ballet dancer

\section{Abstracts}

Any person offering to give a paper relating to one of these themes should send an abstract of 300 words by January 1st, 1982, to the Sectional Chairman of 'Physiotherapy in Sport':

Professor Margaret I. Bullock,

Department of Physiotherapy,

University of Queensland,

ST. LUCIA

Brisbane, Queensland 4067,

Australia.
Abstracts will be submitted for consideration of acceptance to an International Review Board.

To be considered for publication in Conference Proceedings, final papers must be submitted by June 1st, 1982.

Information: Other information may be obtained from 'Physiotherapy in Sport' Sectional Chairman, Professor M. I. Bullock.

\section{BOAT TRIP TO SCANDINAVIA AND RUSSIA \\ 16 - 29 May 1982, to include IX W.C.P.T. World Congress}

Further details of this trip to Copenhagen, Helsinki, Leningrad and Stockholm on Ms Ilmatar can be obtained from Genootschap voor Fysiotherapie, Postbus 248, 3800 AE Amersfoort, Holland, mentioning "Studicreis Scandinavie",

\section{BOOK REVIEW}

Joubert, Z. F. (1981): A unique writing tablet for the disabled. Rehabilitation in S.A., 25, $51-56$.

The article describes a finger writing tablet developed by the author for use by disabled persons who cannot write with a pen and also experience problems when using typewriters. By writing large letters on the writing tablet with a finger (or toe), a message can be set up by an electronic read-out unit, corrected if necessary and then printed by electronic printers. The writing tablet is very adaptable in size and assembly, whilst it can be used for a variety of communicators, writing machines and telecommunicators. It can also be adapted for use by visually handicapped, blind and multihandicapped persons.

Translation of author's summary.

\section{CLASSIFIED}

\section{SALE OF PRIVATE PRACTICE}

For Sale - Busy Private Practice in East London. Apply: Mrs. A. Larsen, $6 \mathrm{St}$ James Road, East London. Telephone: (0431) 2-1754 Office Hours.

\section{FISIOTERAPEUT BENODIG}

Fisioterapeut benodig vir privaat praktyk in Virginia. Uitstekende salaris. Vyfdag week. Skakel (017) 3-4688 (werksure) of (017) 3-2511 (na-ure).

\section{BLUEGUM TRAINING CENTRE}

Physiotherapist required for Cerebral Palsied Adolescents.

Working hours: $08 \mathrm{~h} 30-14 \mathrm{~h} 00+$ school holidays.

Salary: Department of Internal Affairs scale.

Apply: Mrs. Fourie, P.O. Box 3, BONTEHEUWEL, CAPE TOWN, 7763. Telephone (021) 67-5101.

\section{PHYSIOTHERAPIST REQUIRED}

Experienced Physiotherapist required for private practice in Sea Point, Cape, from 1st March, 1982. Knowledge of Maitland techniques a recommendation. Phone (021) 44-8795 after 19 h00.

\section{VACANCY - PHYSIOTHERAPIST}

Full-time Physiotherapist with Maitland and Sport Injury experience required for Private Practice.

Salary and Accommodation negotiable. Telephone (024) 2-2764.

\section{LOCUM REQUIRED}

Locum required for Private Practice in LADYSMITH Natal for \pm six weeks March/April 1982.

For further details phone (0361) 2619 or write to P.O. Box 1014 LADYSMITH, Natal 3370. 